\title{
IFRS Disclosures and Protection of Shareholders' Interests in Nigerian Quoted Firms
}

\author{
Peter Oludare Abe, Ayooluwa Eunice Ajayi-Owoeye and Folajimi Festus Adegbie
}

\begin{abstract}
The protection of shareholders' interests has attracted global attention following the corporate developments around the world necessitating disclosure and financial reporting regulations. A sample of 55 firms quoted on NSE was selected for the period of 2014-2018. The study adopted descriptive and inferential statistics. The regression results also show that IFRS disclosures have significant effect on the protection of shareholders' interests in the selected listed firms in Nigeria at a 5 percent level of significance. The study concluded that there is inverse relationship between the protection of shareholder interests and IFRS disclosures; however, the IFRS disclosures have significant effects on the protection of shareholders in the Nigerian quoted firms. The study recommends that the Financial Reporting Council of Nigeria should change its stance on IFRS from adoption to adaptation in order to allow for local accounting standards that reflect the Nigerian environments.
\end{abstract}

Index Terms - CAMA, Disclosure, IFRS, Protection, Shareholders' Interests.

\section{INTRODUCTION}

Shareholders' wealth maximization is the most acceptable corporate objective, and this is a normal response to financial resources provided by shareholders. Leuz and Wysocki [1] identify three of these global developments that necessitated disclosure and financial reporting regulation: financial crises and corporate scandals; International Financial Reporting Standards (IFRS) adoption; and the increasing internationalization of capital markets. Whether financial or non-financial, IFRS disclosures are important to shareholders as a basis for their decisions and as evidence of the extent of representation and protection of their interests by business firms [2]. IFRS disclosure reporting could also have a psychological effect on the reporting entities and it could help to drive stability and better performance [3]. More than ever, stakeholder management is important first to acknowledge the context of business operations and value creation and secondly to drive sustainability [4]-[6]. However, with the increasing awareness of stakeholders, there have been concerns about if and how the interests of shareholders, the major finance providers, have been considered and protected.

The adoption and adaptation of the International Financial Reporting Standards (IFRS) is now on the increase to drive globalization. IFRS implementation is expected to come with some benefits, which include enabling countries to "break all barriers to international trade; liberalize the economy; attract foreign investors thereby engendering a business-friendly environment for a healthy competition with domestic firms" [7]. Nigeria made the decision to adopt IFRS in 2010, which was phased into three stages and its implementation started in 2012 [7]. The Federal Reporting Council of Nigeria has been charged with the responsibility to promote compliance in Nigeria with the adopted IFRS standards issued by the International Accounting Standards Board [8]. The Body and Act were established and promulgated following the recommendation of the World Bank ROSC Report 2004 [9].

Disclosure is expected to drive a better flow of information for proper decision making between business firms and stakeholders [10], [3] while reducing information asymmetry [11]. However, the recent market and corporate failures are largely attributed to disclosure weakness [12], [13]. The various corporate failures could also be attributed to greedy, corrupt, and incompetent managers [14], whom investors perceive to be accountable to nobody [15]. These corporate failures in the 2000s have raised concerns on how protected shareholder interests are.

Many researches works on disclosure have concentrated on impact of disclosure on performance [3], [16]-[23]. Also, some researchers empirically identify and consider the effect of firm-specific attributes on the level and quality of disclosure [24]-[26]. However, there have been concerns over the years if disclosures in financial statements are relevant to and adequately reflect, represent, and protect the interests of shareholders for sustainability of business organizations.

\section{A. Statement of the Problem}

Post-adoption of IFRS and its mandatory application in Nigeria, studies have shown that disclosures and transparency have improved but still leave much room for regulation and compliance. On a practical level, accounting standard setters acknowledge that financial statements (the main disclosure instrument) serve general-purpose and mostly tailored towards investors and creditors. This creates a vacuum of information needs of users which standard setters have little or no regard for but are rather assumed [27]. Thus useful, specific information needs of shareholders are hardly known [28], [29]. Many business firms would rather not disclose or disclose low-quality information [30], [31]. Inadequate disclosure has been at the heart of most policy analyses of the global financial crisis [12].

While there is legal protection of investors (especially minorities) on paper in most developing countries, there are vast cases of corporate governance failures, little or no 
protection of investors, systemic corruption and weak regulatory and legal frameworks [32]. With disclosures and strong regulatory enforcement, the protection of shareholders could be considerably achieved in developing countries.

From the foregoing on disclosure in developing nations and Nigeria, this study becomes necessary to take the disclosure researches further especially in Nigeria. Studies on statutory disclosure in Nigeria have looked at factors influencing disclosures, quality of disclosure and level of compliance with an undertone of investor protection, largely because our corporate law is shareholder oriented. However, few studies see and assess the adequacy of statutory disclosures to protect stakeholders' interests in Nigeria. The study seeks to establish empirically if IFRS disclosures mean good for shareholders and protect their interests.

\section{B. Objective, Question and Hypothesis of the Study}

The objective of this study is to evaluate the effect of IFRS disclosure on the protection of shareholder interests in Nigerian quoted firms.

Research Question

In what way do IFRS disclosures affect the protection of shareholders' interests in Nigerian quoted firms?

Hypothesis

$\mathrm{H}_{0}$ : IFRS disclosures have no significant effect on the protection of shareholders' interests in Nigerian quoted firms.

\section{REVIEW OF LITERATURE}

\section{A. Shareholders and Protection of their Interests}

While there has been an argument as to whether to refer to stockholders as owners of business firms, Freeman [33] calls them one of the financiers of the business and also a stakeholder. Institutional shareholders are active investors both in good and bad times [34]; however, usually shareholders react and stand up to managers in bad times of underperformance and increasing institutional sales of firm shares [35], [36]. Many corporate laws are shareholderoriented and target to protect the shareholders' interests; even despite different calls to change this orientation to the stakeholder perspective. Nigeria is largely shareholderoriented in her approach to corporate law; however, its corporate governance stance is moving in the direction of stakeholders like other countries [37]. Most countries like the United Kingdom and South Africa have adopted an enlightened shareholder value approach [38]. However, this approach allows firms to pursue shareholder wealth maximization with a long-term perspective while considering and creating value for relevant stakeholders [39]. Porta, Lopez-de-Silanes, Shleifer, and Vishny [40], [41] noted that common law countries tend to provide better protection to minority shareholders than civil law countries do.

By most corporate laws, directors are expected to act in the best interest of the company. This implies that as directors interact with different shareholders and other stakeholders with different conflicting interests, directors strive to achieve the appropriate balance between its various stakeholder groups [42], with shareholders having priority. The following critical components of corporate defense must be managed effectively: governance, risk, security, control, assurance, compliance, intelligence, and resilience [43]. Shareholders and other stakeholders could also engage external auditors, rating agencies and regulators in the event that the organization fails in its obligations to them [43]. Disclosure is an important tool in the hand of business firms and when wielded properly, shareholder protection could be guaranteed. The recent adoption of IFRS by most countries (in 2005 in the EU and 2012 in Nigeria) is intended to drive globalization and protect shareholders who could be beyond the national walls of the reporting entities.

It should be noted that the Nigerian government has made considerable efforts to protect the interests of shareholders in Nigeria. The corporate laws and bodies mostly support the protection of shareholders and creditors, while other regulations and agencies target and protect various corporate stakeholders. While there is no standard non-governmental body to protect the interests of shareholders, different shareholder groups are making efforts to promote their own interests. For example, over 100 shareholders' associations are registered with the Corporate Affairs Commission in Nigeria (SEC. n.d.).

\section{B. International Financial Reporting Standards (IFRS)}

A set of annual reports and accounts (financial statements) has been a major tool of corporate communication and information disclosure for businesses for years [44]. These financial statements are prepared by management based on a set of accounting standards for presentation to shareholders at the annual general meeting. Over the years, different countries have different sets of accounting standards (Generally Accepted Accounting Standards) guiding the preparation and presentation of financial statements. Because of their importance for the attraction of investments and economic growth, accounting standards called IFRS ensure transparency, uniformity, and comparability in preparation and presentation of financial statements on an international basis [45]. Many countries as well as continental and international bodies have moved for their members to adopt IFRS. For example, the EU mandated the adoption of IFRS for its member states from 2005 [46]. Though it is still a subject of academic research, there is an assumption that the adoption of IFRS and U.S. Generally Accepted Accounting Practices (GAAPs) standards leads to quality disclosures as against what obtains in most local reporting regimes outside the Anglo-Saxon sphere [45].

In 2010, Nigeria through the Federal Executive Council approved the adoption of IFRS by Nigerian businesses effectively from 1 January 2012. With the adoption of IFRS to replace the national Statement of Accounting Standards (SASs), corporate disclosure is basically statutory and mandatory in Nigeria. The Financial Reporting Council of Nigeria (FRCN) has also replaced the National Accounting Standard Board through its Act of 2011 and now 'promotes compliance with the adopted standards issued by the International Federation of Accountants and International Accounting Standards Board'.

The idea of IFRS started in 1973 with the establishment of the International Accounting Standards Committee (IASC) by professional accountancy bodies of the United Kingdom and Ireland, United States, Australia, Canada, France, Germany, Japan, The Netherlands, and Mexico. However, 
IASC was restricted until it was changed to International Accounting Standards Board (IASB) in 2001 to meet the demands of globalization and growing informational needs in the market and thus drive transparency, uniformity, and comparability of disclosures. The IASB rolls out accounting standards of global application and appeal in the various capital markets to enhance the decision making of users [47]. However, the quality of IFRS is still a concern to many and thus a subject of research to scholars. Also, cultures have had a major effect on the adoption of IFRS while these sets of standards could not show differences in national business practices arising from differences in institutions and cultures [48].

Nigeria has fully subscribed to all IFRS standards and through the FRCN Act of 2011 has mandated all corporate entities to apply these standards in the preparation of their financial statements. FRCN replaced National Accounting Standard Board (NASB) and currently, SAS has been replaced by IFRS, so there are no national accounting standards in Nigeria.

\section{Theoretical Review}

This study was underpinned on the agency theory and signaling theory. The theory of agency was relevant to this study and this was necessitated by the fact that the company representatives act as agents to shareholders by contract. Thus, it becomes imperative for corporate firms to consider, manage and protect the interests of shareholders in the business both on a short- and long-term basis. The shared value would only be created as shareholders' interests are entrenched in the company's strategy and performance. It has been established that disclosure is an important signaling instrument wielded by board and management. Disclosure is for the purpose of attracting shareholders and to show how truly and fairly the company has fared and as an indication for the sustainability of the shareholders' interests and wealth.

\section{Agency Theory}

Agency theory was popularized by Jensen and Meckling [49]. They defined agency relationship as "a contract under which one or more persons (the principal(s)) engage another person (the agent) to perform some service on their behalf which involves delegating some decision making authority to the agent". Agency theory considers the relationship between principal and agent with the focus on resolving the two problems of conflict of interests and risk-sharing [50]. There are two variants of agency theory that have developed over the years: positive and principal-agent agency theories. Positive agency theory considers the relationship between shareholders and managers only in public companies [50]; however, principal-agent agency theory examines and attempts to resolve agency problems beyond the shareholdermanager's relations. The latter implies that every company is perceived as 'a web of contracts' and relationships [51] involving several interest groups [52] with management mostly at the center as the agent.

The earlier proponents of agency theory were Ross [53] and Mitnick [54], who considered the economic agency theory and institutional agency theory respectively. Generally, because agents may often act to maximize their own interests at the expense of the principal's, the later expends costs on structuring, monitoring and bonding a set of contracts among agents, and also provides incentives to act in principal's interests [49], [53], [55]. Agency costs also include the costs due to the fact that it is not appropriate to monitor all contracts perfectly; this is referred to as residual loss [49]. Both principals and agents incur cost of resolving agency problems (which could be monitoring and bonding costs; pecuniary or non-pecuniary) to drive interest alignment and transparency as well as information symmetry [49], [56]. It should be noted that there are institutions put in place to deal with expected and unexpected social behavior in agency contracts [54].

However, there are some criticisms against the agency theory. Perrow [57] considered that positive agency theory focused on agents as a problem of agency relationship, leaving out principals who could be opportunistic and selfcentered as well. Donaldson [58], Wiseman and GomezMejia [59], Sanders and Carpenter [60], and Pepper and Gore[61] are other critics of agency theory and many have suggested other theories or models to modify or totally replace agency theory. Davis, Schoorman, and Donaldson [62] suggested and popularized stewardship theory with an emphasis on the agents who act in the best interests of the principal and trust is important in such a relationship. Wiseman and Gomez-Mejia [59] put together behavioral agency theory and identify ability, motivation and perfect opportunity as necessary elements for the performance of agents in any agency theory.

Underscoring the relevance of agency to this study, disclosures in financial statements and other governance mechanisms are costs incurred by agents. In this instance, the management and board as agent identify the interests of shareholders and are expected to protect them using IFRS as portrayed in various corporate disclosures.

\section{Signalling Theory}

Signalling theory was originally developed by Spence [63]. From its initial application to the employment market, signaling theory is fundamentally concerned with reducing information asymmetry between two parties [64]. However, it has been widely adopted in corporate reporting to explain disclosure [65]. As a result of the information asymmetry problem, companies signal certain information to investors to show that they are better than other companies in the market for the purpose of attracting investments and enhancing a favorable reputation [66]. The theory examines management's intention and disclosure of relevant and quality information to reduce information asymmetry and conflict of interests among different parties.

Signaling theory is about communication with four elements required for a successful impact of information: signaler, signals, receiver, and feedback [67]. In this regard, managers and directors are the signaler with information as signals, while receivers are basically outsiders who interact with signalers through the feedback. Signaling theory is based on assumptions that any endeavor is an investment in uncertainty; that signaling comes at a cost (financial or otherwise); and that there is a feedback loop [63]. Some proponents of this theory focused on the source of financing a project (in line with pecking order theory) as a signal from the management to the investment community [68], [69]. Others also provided evidences on dividends and share buybacks as containing important information contents [70]- 
[72].

The fact that signaling theory has its root in asymmetric information, has a lot to say about the quality and frequency of information and disclosure. This could also be a criticism of the theory and inaction could have the same effect or higher effect than disclosure. Watts [73] and Gonedes [74] were among the critics of the signaling theory, who found no evidence of dividend as signals with important information contents. Stiglitz [75] posits that action and inaction to disclose information alter behaviors of receivers at the other end; thus information imperfection has serious implications. Significantly, disclosure is one of the signaling means and IFRS disclosures are expected to be positive signals that the reporting firms are better than others and could attract investors locally and globally.

\section{Empirical Review: IFRS Disclosure Requirements and Protection of Shareholders' Interests}

Many IFRS studies focused on corporate performance covering the general market as well as specific industries in Nigeria. Also, periods of studies vary - some looked at both pre-IFRS and post-IFRS adoption; others considered the post-IFRS period on performance. Edogbanya and Kamardin [20] carried out a study on company reporting transparency and firm performance in Nigeria. The study showed that transparency of relevant information could lead to firm performance as shown by the significant relationship (positive with Tobin's $\mathrm{Q}$ and negative with ROA) of transparency of board and transparency in financial have positive relationship with Tobin's Q. Okoye, Okoye, and Ezejiofor [9] adopted descriptive design to study the impact of the IFRS adoption on stock market movement in Nigerian corporate organizations. The study concludes that the adoption of IFRS in Nigeria would enhance credible financial statements.

Ironkwe and Oglekwu [22] focused on manufacturing firms (a sample of ten) to ascertain how the adoption of IFRS in Nigeria impacts their performance. The study shows that there is no significant impact of Pre/Post Adoption of IFRS on EPS and ROE. Aseoluwa and Jelil [18] also studied IFRS adoption and performance specifically in quoted consumer firms in Nigeria (10 firms sampled) for a period of 5 years (2010-2014). The findings show that there is no significant relationship between the adoption of IFRS and performance (firm value and ROA) of manufacturing firms listed on the NSE.

Ayodele and Afolabi [3] investigated the relationship between corporate financial disclosure and Nigerian banks' performance and stability with focus on shareholders. The study concludes that corporate financial disclosure has a significant influence on the banks' stability and performance in the Nigerian financial sector. Akinleye [17] and Yahaya, Fagbemi, and Oyeniyi [23] were other studies on banks with respect to their adoption of IFRS and its effects on performance with both studies concluding significant influence on bank's performance.

Ibanichuka and Asukwo [21] sampled ten listed petroleum marketing companies, covering pre-IFRS and post-IFRS adoption periods. The study concluded that there is no significant relationship between IFRS adoption and the corporate performance of petroleum marketing entities in
Nigeria. Other studies on IFRS adoption and performance in Nigeria oil and gas companies were carried out by Adelusi and Ibigbami [16] and Donwa, Mgbame and Idemudia [19] with both studies also concluding that there was no significant difference between the two regimes.

In other studies, researchers' interests were on the effect of IFRS adoption on the quality of disclosures. These studies also vary in terms of instruments and coverage of the general market and specific industries. Sanyaolu, Lawal, and JobOlatunji [76] sampled fifty experts for their perception of IFRS adoption and the quality of financial statements. While the study shows that there is a significant relationship between IFRS adoption and the timeliness as well as are reliability of financial statements, however the study also revealed that there is no significant relationship between IFRS adoption and the relevance of financial statement. Ilu and Yunusa [77] investigated the perceived confidence of stakeholders on financial statements after the adoption of IFRS using survey design. The results of the study showed that IFRS implementation will promote the confidence of stakeholders in financial statement reporting and reduce information irregularity and strengthen the communication link between all stakeholders.

Zaiyol, Andrew, and Udende [78] also understudied IFRS adoption and the quality of disclosures, with twenty listed companies randomly selected for two periods: 2011 NGAAP and 2015 IFRS. The study, therefore, concludes that IFRS have impacted on accountability and quality of information from the financial statement of Nigerian organization. Nwoye, Chidoziem, Obiorah, and Ekesiobi [79] empirically assessed the impact of the quality of IFRS compliance on the acceptability of financial reporting of Nigerian banks. The outcome of the analysis showed that the level of compliance of Nigerian banks to IFRS disclosure guidelines has indeed improved the acceptability of her financial reporting practices globally. It was also discovered that significant contributions were made by the independent variables in explaining the compliance quality level of IFRS disclosure practices upheld by the Nigerian banks. Adebisi, Otuagoma, and Abah [80] also focused on banks for the period of 2012- 2015 and their study concludes that there is an increase in the IFRS disclosure compliance and this has a positive relationship with the quality of financial reporting.

\section{E. Gaps in the Literature}

Most studies covered up to 2015 [78], [80]-[83]. From the empirical studies above, the period of most of the studies needs to be updated to reflect the currency of disclosures and their impacts on shareholders.

Abata [84], Adetoso [85], and Sanyaolu, Lawal, and JobOlatunji [76] used the survey instrument (questionnaire) to study the adoption and implementation of IFRS in Nigeria. Mostly survey research design is targeted to harvest the perceptions of stakeholders often subject to different emotions and may not necessarily capture the impact of IFRS disclosures on stakeholders like ex-post facto research design would do. This research followed the majority of studies using ex-post facto design and panel regression analysis was applied to the data collected.

While studies on specific industries are well appreciated, most of the conclusions may not be a good inference for the 
whole market; thus there are needs for studies to cover all sectors and a good number of firms for good generalization and application to the listed companies on the NSE.

These gaps form the major basis for this research in order to the effect of IFRS disclosures on the protection of shareholders' interests in Nigeria.

\section{F. Justification for the Study}

Disclosure weakness has been adjudged as a pivotal cause of financial crises and corporate failures as witnessed globally [13], [86] and specifically in Nigeria [3] Owolabi, [87]. With shareholders having financial interests in the business firm, it becomes imperative for disclosure to adequately reflect and meet the informational needs of these shareholders for effective decision making, proper protection and in the long term ultimate sustainability of the company [88], [89].

Bushman, Piotroski, and Smith [90] noted that mandatory disclosures improve the intensity, informativeness, timeliness, and credibility of bank disclosure. Banking crises are less likely in countries with greater regulated disclosure and transparency [91]. Information asymmetry and externality are two major problems that firms and their shareholders face with little or no self or internal help except through regulated disclosure [91], [92]. In this regard, research has shown that the mandatory IFRS disclosures in Nigeria has played a vital role in improving performance. However, it is observed from the literature review that there is no comprehensive research on the adequacy of statutory disclosures to protect the interests of shareholders and this is a gap the study wants to fill, coupled with the need to update the study on compliance with statutory disclosure requirements as disclosures change as economies change. The general assumption is that corporate disclosures do protect shareholders' interests. This assumption, however, requires empirical testing in Nigeria which is the purpose of this study. The current statutory IFRS disclosures in Nigeria would be empirically tested to evaluate their effects on the protection of shareholders under study.

\section{Methodology}

The ex-post facto research design was used in the study of the relationship between and effect of the dependent and the independent variables of the subject of study. The population of interest for this research composed of all the listed equities on the Nigerian Stock Exchange (NSE) as of 31 December 2018. There were 168 firms listed on the equity section of the exchange and they were divided into four boards - 147 firms on the main board, 7 firms on the premium board, 9 firms on the Alternative Securities and Exchange Market (ASEM) and 5 firms on the Real Estate Investment Trust and ClosedEnded Fund (REITCEF) of the NSE. The equities market consists of 11 sectors namely: Agriculture, Conglomerates, Construction/Real Estate, Consumer Goods, Financial Services, Healthcare, Information and Communication Technology (ICT), Industrial Goods, Natural Resources, Oil and Gas, and Services. Stratified random sampling technique was adopted in the selection of the sample from the population of the firms listed on the equities market of the NSE. The study covered five years for the period of 2014
2018. Yamene's [93] formula was adopted to determine the sample of the quoted firms for this study. The samples for this study were 55 firms for each period. This represented about $33 \%$ of the population of the quoted Nigerian firms on the equities market at the NSE.

\section{A. Data Collection and Analysis}

This study made use of secondary data. The annual reports were gotten from the NSE website, Bloomberg and individual company's websites. The annual reports had been subjected to statutory external audit as required by the Companies and Allied Matters Act 2004 (as amended), thus certified as true and fair representation of corporate performance, and could be relied on. Also, these reports had been submitted to and approved by the respective industry regulators and are meant to meet some standard requirements before release to and use by the general public.

The researcher analyzed the corporate annual reports to identify the interests of shareholders and used a selfconstructed checklist for disclosures of International Financial Reporting Standards (IFRS). For the purpose of this study, the IFRS covered 23 standards (IFRS 2, 3, 5, 7, 8, 12, 13, IAS 1, 2, 7, 10, 12, 16, 19, 21, 23, 24, 26, 33, 36, 37, 38, 40) and a checklist consisting 80 items of disclosure requirements was constructed. The selected accounting standards were based on their relevance and application to both financial and non-financial companies. However, the excluded standards are for reasons of irrelevance to annual reports, being industry-specific, required in certain circumstances, replaced by another standard or outside the periods of the study. The protection of shareholder interests was represented by EPS (earnings per share). Each proxy was analyzed against the IFRS disclosures. The regression analysis method was adopted for this study and EView software was used to analyze the data and the variable statistics were interpreted based on the outcome of the result.

The model below was adopted to establish the effects of IFRS disclosures on the protection of shareholders' interests. Disclosure requirements under IFRS are expected to have a positive impact on the protection of shareholders' interests.

$$
\operatorname{PSIT}_{i t}=\alpha+\beta_{1} I F R S_{i t}+\varepsilon_{i t}
$$

where PSIT = protection of stakeholders' interests; IFRS = International Financial Reporting Standards; $\alpha=$ the constant of the variables;

$\beta_{1}=$ coefficient of the parameter estimates;

$\varepsilon=$ the error term of the linear model.

\section{Data Analysis, Results And Discussion OF FINDINGS}

\section{A. Descriptive Statistics for Selected Listed Firms of the Nigerian Stock Exchange}

Table 1.1 shows the mean, maximum, minimum, and standard deviation values of the following variables: The dependent variable is Earnings Per Share (EPS). The explanatory variable is the International Financial Reporting Standards (IFRS). All the values were calculated from the 275 firms-year observations for fifty-five listed firms in Nigeria. 
TABLE 1: DESCRIPTIVE STATISTICS FOR IFRS DISCLOSURES ON THE PROTECTION OF SHAREHOLDERS' INTERESTS VARIABLES

\begin{tabular}{cccccc}
\hline $\begin{array}{c}\text { Variable } \\
\mathrm{s}\end{array}$ & $\begin{array}{c}\text { Mea } \\
\mathrm{n}\end{array}$ & $\begin{array}{c}\text { Maximu } \\
\mathrm{m}\end{array}$ & $\begin{array}{c}\text { Minimu } \\
\mathrm{m}\end{array}$ & $\begin{array}{c}\text { Std. } \\
\text { Dev. }\end{array}$ & $\begin{array}{c}\text { Observation } \\
\mathrm{s}\end{array}$ \\
\hline EPS & 2.98 & 54.26 & -23.00 & 7.21 & 275 \\
IFRS & $\begin{array}{c}61.0 \\
6\end{array}$ & 76.00 & 47.00 & 7.64 & 275 \\
\hline
\end{tabular}

Source: Author's computation (2019), underlying data from annual reports of firms listed on NSE.

Earnings per share (EPS): In Table 1, the mean value of earnings per share is 2.98. This shows that on average the selected listed firms give back to their shareholders and there is a value on their investments. The maximum value of 54.26 and the minimum value of -23.00 further suggest that there is a disparity in their degrees of efficiency among the selected listed firms. Thus, some firms are creating high returns for their shareholders, while some are operating at a loss.

International Financial Reporting Standards (IFRS): In Table 1, the mean value of the International Financial Reporting Standards (IFRS) is 61.06; this value is encouraging because out of a possible 80 qualitative values, it shows that the listed firms adhered to the IFRS practices. The maximum value is 76 and the minimum value is 47 . This further suggests that the adherence to the IFRS practices differs and that none of the listed firms adhered fully to IFRS practices.

\section{B. Pearson Correlation}

Table 2 shows the Pearson pairwise correlation matrix. The results show that earnings per share have a negative relation with disclosures of International Financial Reporting Standards (IFRS). This implies that increases in the IFRS disclosures will lead to a fall in the protection of shareholders (as measured in this study using earnings per share) of the selected listed firms.

TABLE 2: CORRELATION MATRIX FOR STATUTORY DiSClOSURES ON THE PROTECTION OF STAKEHOLDERS' INTERESTS VARIABLES

\begin{tabular}{ccc}
\hline Variables & EPS & IFRS \\
\hline EPS & 1.00 & \\
IFRS & -0.07 & 1.00
\end{tabular}

Source: Author's computation (2019), underlying data from annual reports of firms listed on NSE.

\section{Presentation of Regression Results}

TABLE 3: EFFECT OF IFRS DISCLOSURES ON PROTECTION OF SHAREHOLDERS INTERESTS

\begin{tabular}{cc}
\hline Dependent Variable: & EPS \\
\hline Coefficients - IFRS & $2.527^{* * *}$ \\
Standard Error & $(0.183)$ \\
T-test & 13.796 \\
Prob value & 0.000 \\
Coefficients - Constant & -3.155 \\
Standard Error & $(-7.459)$ \\
T-test & -0.423 \\
Prob value & 0.672 \\
\hline Diagnostic test & \\
$R^{2}$ & 0.31 \\
Hausman Test & $0.01(0.92)$ \\
Bresuch-Pagan RE Test & $22.22(0.00)$ \\
Heteroscedasticity Test & $34.11(0.00)$ \\
Serial Correlation Test & $139.89(0.00)$ \\
Accepted Model & RE \\
Observations & 275 \\
\hline
\end{tabular}

Source: Author's computation (2019), underlying data from annual reports of firms listed on NSE.

Notes: Table 3 reports panel data regression of the effect of disclosure requirements of IRFS on the protection of shareholders' interests. The dependent variable is Earnings Per Share (EPS), while the explanatory variable is the International Financial Reporting Standards (IFRS). RE and DK denote Random Effect Model and Driscoll-Kraay Model respectively. The $t$ statistics are in parentheses.

${ }^{*}$ Significant at $10 \%,{ }^{* *}$ Significant at $5 \%,{ }^{* * *}$ Significant at $1 \%$.

D. The Effect of Disclosure Requirements of IFRS on Earnings per Share

The results show that the disclosure requirements of the International Financial Reporting Standards have a significant effect on earnings per share of listed firms in Nigeria $(I F R S=2.527, t$-test $=13.796, p=0.000)$. The magnitude of the estimated parameters for the coefficient is 2.527; this implies that a unit increase in the disclosure requirements of the International Financial Reporting Standards will lead to 2.527 increases in earnings per share of the firms in Nigeria. The R2 $=0.31$ which measures the proportion of the changes in earnings per share as a result of changes in the disclosure requirements of the International Financial Reporting Standards explains about 31 percent changes in earnings per share of listed firms in Nigeria, while the remaining 69 percent were other factors explaining changes in earnings per share in Nigeria but were not captured in the model.

Therefore, the t-statistic of 13.796 is statistically significant with $\mathrm{p}<0.05$ indicating that the null hypothesis that there is no significant relationship of IFRS disclosure requirements on the protection of stakeholders' interests (earnings per share) in Nigerian quoted firms was rejected. Thus, the alternative hypothesis that there is a significant relationship between IFRS disclosure requirements on the protection of stakeholders' interests (earnings per share) in Nigerian quoted firms was accepted at a 5 percent level of significance.

\section{E. Discussion of Findings on IFRS Disclosures and Protection of Shareholders' Interests}

he findings of this study indicate that the disclosure requirements of IFRS have a statistically significant impact on the protection of shareholders' interests under study. This is in line with our apriori expectation that the disclosure requirements of IFRS would have a significant impact on the protection of shareholders' interests in Nigerian quoted firms. This implies that the disclosure requirements of the IFRS are significant factors influencing the protection of shareholders' interests of selected listed firms in Nigeria. The results of this study support the findings of some previous researchers in the area of study.

The findings from this study are supported by the works of Akinleye [17] and Yahaya, Fagbemi, and Oyeniyi [23], where some banks were sampled in respect to their adoption of IFRS and its effects on performance with both studies concluding significant influence on bank's performance and consequently promoting shareholders' interests. Ayodele and Afolabi [3] also supported the results of this study; their research investigated the relationship between corporate financial disclosure and Nigerian banks' performance and stability and concluded that corporate financial disclosure has a significant influence on the banks' stability and performance in the Nigerian financial sector. Adebisi, Otuagoma, and Abah [80], Adetoso [85], Ilu and Yunusa [77], and Nwoye, Chidoziem, Obiorah, and Ekesiobi [79] are other studies in line with the findings of this study; they 
concluded that there is an increase in the IFRS disclosure compliance and this has a positive relationship with the quality of financial reporting.

However, this study's empirical results negate the findings of Adelusi and Ibigbami [16] and Donwa, Mgbame and Idemudia [19] and Ibanichuka and Asukwo [21] on IFRS adoption and performance in Nigeria oil and gas companies and their studies concluded that there is no significant relationship between IFRS adoption and corporate performance in Nigeria in both pre- and post-IFRS adoption regimes. The same conclusion of no significant relationship was also reached by Aseoluwa and Jelil [18] and Ironkwe and Oglekwu [22] in their studies to ascertain how the adoption of IFRS impacts the performance of manufacturing firms in Nigeria.

\section{F. Implications of Findings}

FRCN has the enormous responsibility to implement and ensure compliance with accounting standards and code of corporate governance by all corporates in Nigeria. The study shows that disclosures of IFRS have negative or inverse association with the protection of interests of shareholders. This implies that shareholders may have to look for protection beyond the statutory disclosures. This shows that there are still gaps in IFRS disclosures, and thus creating loopholes for some corrupt corporate managers to exploit. This is a big challenge for FRCN to take up and to avoid a total breakdown of these regulations and consequently the market and economy failure in general.

The results of this study, that disclosure regulation requirements of IFRS have significant effect on the protection of stakeholders' interest, will provide more evidence and impetus for FRCN to pursue their roles regarding accounting standards and thus ensure that the relationship between IFRS disclosures and protection of shareholders across turns positive.

The findings of this study show that disclosure requirements of IFRS have significant effects on the protection of shareholders' interests. Previous studies have also shown that disclosures improve performance. This, in turn, implies that the sustainability of corporate performance is dependent on disclosures and consequently on the shareholders as they read between the lines that their interests are protected. Firms should ensure that strategies and oversight mechanisms are put in place to ensure sustainable business practices for subsequent disclosures and protection of shareholders' interests. Also, the management should put in place policies and operations for business sustainability and prioritize disclosures.

The findings of this research emphasize that the interests of shareholders should be considered and protected by corporate firms through the instrument of IFRS disclosures. The study's results would empower shareholders to push for compliance with all disclosure regulations and to have legal impetus in this regard. Through the empirical results of this study, shareholders would only invest or keep their investments if business firms protect their interests beyond the IFRS disclosures.

The research supports the signaling theory. This study empirically established that requirements of IFRS disclosure have a significant effect on the protection of shareholders' interests. Thus, as disclosure requirements are complied with, they signal that the interests of shareholders are and would be protected. Also, the negative significant relationship of disclosures of IFRS with the protection of shareholder interests would be a signal to shareholders. The results of this study would have implications on the quality and timeliness of disclosures to close the gap of information asymmetry between the management and stakeholders. Likewise, the study will add to the existing knowledge of stakeholders and disclosure.

\section{CONCLUSION AND RECOMMENDATIONS}

\section{A. Conclusion}

The purpose of this study was to evaluate the effect of IFRS disclosures on the protection of shareholders' interests in the 55 sampled Nigerian quoted firms for a five-year period covering 2014-2018. A checklist of some International Financial Reporting Standards (IFRS) was constructed and analyzed against Earnings Per Share (EPS) as proxy for protection of shareholders' interests through descriptive statistics, correlations, regressions, and other econometric models; the findings were presented and interpreted accordingly.

Through the descriptive statistics of this study, the researcher concludes that none of the listed firms adhered fully to IFRS practices, which could be attributable to many reasons. The findings of this study indicate that the disclosure requirements of International Financial Reporting Standards have a statistically significant impact on the protection of the shareholders' interests under study. However, the inverse relationship between the protection of shareholder interests and IFRS disclosures is worrisome and this needs urgent attention, as loss of investment could threaten the sustainability of business firms.

\section{B. Recommendations}

The study recommends that the Financial Reporting Council of Nigeria (FRCN), the national body in charge of adoption and enforcement of IFRS disclosures in Nigeria, should change their stance on IFRS from adoption to adaptation to local GAAPs to drive and achieve full compliance. In other words, there is a need to localize the accounting standards and to factor in the reality of the Nigerian environments into the formulation and implementation of these standards. The protection of shareholder investment to a large extent determines the existence of the business firm and other stakeholders would only have a conversation on their interests when the business and investment are sustained.

The inverse relationship between IFRS disclosures and the protection of shareholders shows that IFRS disclosures may not be enough to protect their interest. It is therefore recommended that shareholders should look beyond mandatory IFRS disclosures for their investments within the legal means. This could be done by championing policies and principles to capture their interests in the available disclosure regulations. Voluntary disclosures could also be advocated to capture information beyond the statutory disclosures. 


\section{Contribution to Knowledge}

This study has shown that IFRS disclosures have significant effects on the protection of stakeholders' interests. The economic and financial experts have continuously reverted to mandatory regulations and thus the importance of mandatory IFRS disclosures cannot be overemphasized; thus, developing economies like Nigeria have to get it right first with statutory disclosures. This study thus will help to sensitize FRCN to enforce compliance.

This study was underpinned on signaling theory and has shown that IFRS disclosures are signals from the organization on the interests of shareholders. While significance is well noted, the relationship between the variables under study signal the direction where the shareholder groups would go to get their desired protection. It also further established that management are agents to shareholders.

The currency of this research work to reflect disclosures and their effects on shareholders is an improvement to previous works in this regard. Most studies covered up to 2015 [78], [80]-[83], except for the work of [94], who extended to year 2016.

Most importantly, this study contributed to the body of knowledge on disclosure and sustainability of business firms in Nigeria particularly from the view of shareholders and the protection of their interests. This study has contributed theoretically and empirically to the discourse and has proffered some set of recommendations to protect the shareholders' interests in the firms listed on the Nigerian Stock Exchange.

\section{REFERENCES}

[1] Leuz, C., \& Wysocki, P. (2016). The economics of disclosure and financial reporting regulation: Evidence and suggestions for future research. Journal of Accounting Research, 54(2), 525-622.

[2] Elfeky, M. I. (2017). The extent of voluntary disclosure and its determinants in emerging markets: Evidence from Egypt. Journal of Finance and Data Science, 3(1-4), 45-59.

[3] Ayodele, T. D., \& Afolabi, T. S. (2018). Corporate financial disclosure in Nigerian deposit money banks. Advances in Social Sciences Research Journal, 5(2) 248-253.

[4] Krstic, N. (2014). Stakeholder management from the business perspective. Megatrend review, 11(2), 165-182.

[5] Perrini, F., \& Tencati, A. (2006). Sustainability and stakeholder management: The need for new corporate performance evaluation and reporting systems. Business Strategy and the Environment, 15(5), 296-308.

[6] Post, J. E., Preston, L. E., \& Sachs, S. (2002). Managing the extended enterprise: The new stakeholder view. California Management Review, 45(1), 6-28.

[7] Achugamonu, B. U., Olokoyo, F. O., Babajide, A. A., Owolabi, F., \& Adetula, D. T. (2016). Adoption of international financial reporting standards and its implication on bank performance in Nigeria: A comparative approach. Journal of Internet Banking and Commerce, 21(S5), 1-20.

[8] Financial Reporting Council of Nigeria Act (2011)

[9] Okoye, P.V.C., Okoye, J.F.N., \& Ezejiofor, R. A. (2014). Impact of the IFRS adoption on stock market movement in Nigerian corporate organization. International Journal of Academic Research in Business and Social Sciences, 4(9), 202-218.

[10] Archambault, J. J., \& Archambault, M. E. (2003). A multinational test of determinants of corporate disclosure. Finanse, Rynki Finansowe, Ubezpieczenia, 74(2), 245-258.

[11] Oyerogba, E. O. (2014). Risk disclosure in the published financial statements and firm performance: Evidence from the Nigeria listed companies. Journal of Economics and Sustainable Development, 5(8), 86-95.
[12] Avgouleas, E. (2009). The global financial crisis, behavioural finance and financial regulation: In search of a new orthodoxy. Journal of Corporate Law Studies, 9(1), 23-59.

[13] Zingales, L. (2004). The costs and benefits of financial market regulation. ECGI - Law Working Paper, 21, 1-57.

[14] Norman, W. (2004). What can the stakeholder theory learn from Enron? Ethics and Economics, 2(2), 1-12.

[15] Zingales, L. (2009), The future of securities regulation. Journal of Accounting Research, 47(2), 391-425.

[16] Adelusi, A. I., \& Ibigbami, S. A. (2017). The international financial reporting standard (IFRS) adoption and the profitability of selected quoted oil and gas companies in Nigeria. International Journal of Operational Research in Management, Social Sciences \& Education, 3(2), 27-41

[17] Akinleye, G. T. (2016). Effect of international financial reporting standards (IFRS) adoption on the performance of money deposit banks in Nigeria. European Journal of Business, Economics and Accountancy, 4(4), 487-95.

[18] Aseoluwa, A. C. N., \& Jelil, A. A. (2017). IFRS adoption and performance of quoted consumer goods manufacturing companies in Nigeria. Archives of Business Research, 5(9), 128-138.

[19] Donwa, P. A., Mgbame, C. O., \& Idemudia, N. G. (2015). Effect of IFRS on accounting ratios in Nigeria oil and gas companies (A Comparative Analysis). Journal of Accounting and Financial Management, 1(8), 67-76.

[20] Edogbanya, A., \& Kamardin, H. (2016). Company reporting transparency and firm performance in Nigeria. Asia Pacific Journal of Advanced Business and Social Studies, 2(2), 346-356.

[21] Ibanichuka, E. A. L., \& Asukwo, I. S. (2018). International financial reporting standards adoption and financial performance of petroleum marketing entities in Nigeria. International Journal of Advanced Academic Research Accounting \& Economic Development, 4(2), 1 15.

[22] Ironkwe, U. I., \& Oglekwu, M. (2016). International financial reporting standards (IFRSs) and corporate performance of listed companies in Nigeria. International Institute of Academic Research and Development, 2(3), 1 -13.

[23] Yahaya, K. A., Fagbemi, T. O., \& Oyeniyi, K. K. (2015). Effect of international financial reporting standards on the financial statements of Nigerian banks. Journal of Agricultural Economics, Environment and Social Sciences, 1(1), $18-29$.

[24] Mogudu, K. P., \& Eboigbe, S. U. (2017). Corporate attributes and corporate disclosure level of listed companies in Nigeria: A post-IFRS adoption study. Journal of Finance and Accounting, 5(2), 44-52.

[25] Owusu-Ansah, S. (1998). The impact of corporate attributes on the extent of mandatory disclosure and reporting by listed companies in Zimbabwe. The International Journal of Accounting, 33(5), 605-631.

[26] Umoren, A.O (2009) Accounting Disclosures and corporate Attributes: Evidence from Nigerian Stock Exchange. Unpublished Ph.D Thesis. Covenant University, Ota, Nigeria.

[27] Young, J. J. (2006). Making up users. Accounting, Organizations and Society, 31(6), 579-600.

[28] Cascino, S., Clatworthy, M., Osma, B. G., Gassen, J., Imam, S., \& Jeanjean, T. (2013). The use of information by capital providers: Academic literature review. Institute of Chartered Accountants of Scotland and European Financial Reporting Advisory Group.

[29] Degeorge, F., Ding, Y., Jeanjean, T., \& Stolowy, H. (2013). Analyst coverage, earnings management and financial development: An international study. Journal of Accounting \& Public Policy, 32, 1-25.

[30] Devalle, A., \& Rizzato, F. (2012). The quality of mandatory disclosure: the impairment of goodwill. An empirical analysis of European listed companies. Procedia Economics and Finance, 2, 101 108.

[31] Devalle, A., \& Rizzato, F. (2013). The quality of disclosure in the annual report: Analysis of different approaches. Business Review: Advanced Applications, Cambridge Scholars Publishing, 87-105.

[32] Chizea, J. J., \& Isukul, A. C. (2018). A meta-analysis of corporate governance in a developing country. Journal of Economics and Business, 1(1), 83-99.

[33] Freeman, R. E. (2017). Five challenges to stakeholder theory: A report on research in progress. In D. M. Wasieleski, J. Weber (ed.) Stakeholder Management. Business and Society, 360(1). Emerald Publishing Limited (pp.1 - 20).

[34] Jandik, T., \& McCumber, W. R. (2018). Creditor governance. $\begin{array}{llll}\text { Retrieved on January } 31, & & & \end{array}$ http://dx.doi.org/10.2139/ssrn.3209460.

[35] Aggarwal, R., Saffi, P., \& Sturgess, J. (2015). The role of institutional investors in voting: Evidence from the securities lending market. Journal of Finance, 70(5), 2309-2346. 
[36] McCahery, J. A., Sautner, Z., \& Starks, L. T. (2016). Behind the scenes: The corporate governance preferences of institutional investors. The Journal of Finance, 71(6), 2905-2932.

[37] Rossouw, G. J. (2008). Balancing corporate and social interests: Corporate governance theory and practice. African Journal of Business Ethics, 3(1), 28-37.

[38] Sarkar, S. (2015). The comply-or-explain approach for enforcing governance norms. Indira Gandhi Institute of Development Research, $1-22$.

[39] Millon, D. K. (2016). Enlightened shareholder value, social responsibility, and the redefinition of corporate purpose without law. Washington \& Lee Legal Studies Paper No. 2010-11. Retrieved from http://dx.doi.org/10.2139/ssrn.1625750

[40] Porta, R., Lopez-De-Silanes, F., Shleifer, A., \& Vishny, R. (2000). Investor protection and corporate governance. Journal of Financial Economics, 58(1-2), 3-27.

[41] Porta, R., Lopez-De-Silanes, F., Shleifer, A. and Vishny, R. (2002) Investor protection and corporate valuation. The Journal of Finance, 57(3), 1147-1170

[42] Freeman, R. E., \& J. McVea. (2001). A stakeholder approach to strategic management. In M. Hitt, R. E. Freeman, \& J. Harrison (Eds.) Handbook of strategic management, (pp. 189-207). Oxford: Blackwell.

[43] Lyons, S. (2011). Corporate oversight and stakeholder lines of defense. Conference Board, 365, 1-10.

[44] Hassan, O. A. G., Giorgioni, G., \& Romilly, P. (2006). The extent of financial disclosure and its determinants in an emerging capital market: The case of Egypt. International Journal Accounting, Auditing and Performance Evaluation, 3(1), 41-67.

[45] Daske, H., \& Gebhardt, G. (2006), International financial reporting standards and experts' perceptions of disclosure quality. Abacus, 42(3-4), 461-498.

[46] Consoni, S., \& Colauto, R. M. (2016). Voluntary disclosure in the context of convergence with International Accounting Standards in Brazil. Review of Business Management, 18(62), 658-677.

[47] Atu, O. G., Raphael, I. A., \& Atu, O. O. K. (2016). Challenges of the implementation of IFRS in less developed and developing countries. Igbinedion University Journal of Accounting, 1(1), 1-26.

[48] Armstrong, C. S., Barth, M. E., Jagolinzer, A. D., \& Riedl, E. J. (2010). Market reaction to the adoption of IFRS in Europe. The Accounting Review, 85(1), 31-61.

[49] Jensen, M. C., \& Meckling, W. H. (1976). Theory of the firm: Managerial behavior, agency costs and ownership structure. Journal of Financial Economics, 3(4), 305-360.

[50] Eisenhardt, K. (1989). Agency theory: An assessment and review. The Academy of Management Review, 14(1), 57-74.

[51] Coase, R. H. (1937), The nature of the firm. Economica, 4(16), 386405.

[52] Ittonen, K. (2010). A theoretical examination of the role of auditing and the relevance of audit reports. Proceedings of the University of Vaasa, Teaching Aid Series. Vaasa: Vaasan yliopisto. Retrieved on May 19, 2019 from www.uva.fi.

[53] Ross, S. A. (1973). The Economic Theory of Agency: The Principal's Problem. The American Economic Review, 63(2), 134-139. Retrieved April 14, 2020, from www.jstor.org/stable/1817064.

[54] Mitnick, B. M. (1975). The Theory of Agency: The Policing "Paradox" and Regulatory Behavior. Public Choice, 24, 27-42. Retrieved from www.jstor.org/stable/30022842.

[55] Fama, E., \& Jensen, M. (1983). Separation of ownership and control. Journal of Law and Economics, 26(2), 301-25.

[56] Adams, M. (1994). Agency theory and the internal audit. Managerial Auditing Journal, 9(8), 8-12.

[57] Perrow, C. (1986). Economic theories of organization. Theory and Society, 15, 11-45.

[58] Donaldson, L. (1990). The ethereal hand: Organizational economics and management theory. Academy of Management Review, 15(3), 369-381.

[59] Wiseman, R., \& Gomez-Mejia, L. (1998). A behavioral agency model of managerial risk taking. Academy of Management Review, 23(1) 133-153.

[60] Sanders, G. \& Carpenter, M. (2003). A behavioral agency theory perspective on stock repurchase program announcements. Academy of Management Journal, 46(3), 160-178.

[61] Pepper, A., \& Gore, J. (2012). Behavioral agency theory new foundations for theorizing about executive compensation. Journal of Management, 41(4), 1045-1068.

[62] Davis, J., Schoorman, F., \& Donaldson, L. (1997). Toward a stewardship theory of management. Academy of Management Review, 22(1), 20-47.
[63] Spence, M. (1973). Job market signaling. Quarterly Journal of Economics, 87(3), 355-374.

[64] Spence, M. (2002). Signaling in retrospect and the informational structure of markets. American Economic Review, 92, 434-459.

[65] Ross, S. A. (1977). The determination of financial structure: The incentive signaling structure. Bell Journal of Economics, 8, 23-40.

[66] Verrecchia, R. E. (1983). Discretionary disclosure. Journal of Accounting and Economics, 5(3), 179-194.

[67] Connelly, B. L., Hoskisson, R. E., Tihanyi, L., \& Certo, S. (2010). Ownership as a form of corporate governance. Journal of Management Studies, 47(8), 1561-1589.

[68] Akorsu, P. K. (2014). Testing the pecking order and signalling theories for financial institutions in Ghana. Research Journal of Finance and Accounting, 5(16), 77-83.

[69] Miglo, A. (2011). Trade-off, pecking order, signaling, and market timing Models. In H. K. Baker \& G. S. Martin (Eds.), Capital structure and corporate financing decisions: Theory, evidence, and practice (pp. 171-191). Wiley and Sons, Ch. 10.

[70] Asquith, P., \& Mullins, D. W. (1986). Signalling with dividends, stock repurchases, and equity issues. Financial Management, 15(3), 27-44.

[71] McNally, W. (1999). Open Market Stock Repurchase Signaling. Financial Management, 28(2), 55-67. Retrieved April 14, 2020, from www.jstor.org/stable/3666195.

[72] Reddy, K. S., Nangia, V. K., \& Agrawal, R. (2013). Share repurchases, signalling effect and implications for corporate governance: Evidence from India. Asia-Pacific Journal of Management Research and Innovation, 9(1), 107-124.

[73] Watts, R. L. (1973). The information content of dividends. Journal of Business, 46(2), 191-211.

[74] Gonedes, J. (1978). Corporate signaling, external accounting, and capital market equilibrium: Evidence on dividends, income, and extraordinary items. Journal of Accounting Research, 16(1), 16-79.

[75] Stiglitz, J. E. (2002). Information and the change in the paradigm in economics. American Economic Review, 92, 460-501.

[76] Sanyaolu, W. A., Lawal, A. A., \& Job-Olatunji, K. A. (2017). IFRS adoption and quality of financial statement: Perspective of auditors, chartered accountants and graduates of accounting. International Journal of Innovative Finance and Economics Research, 5(2), 1-10.

[77] Ilu, A. S., \& Yunusa, I. (2018). Adoption of IFRS and financial statements effects: The perceived confidence of stakeholders in Nigerian money deposit banks. Journal of Accounting and Financial Management, 4(7), 1-8.

[78] Zaiyol, P. I., Andrew, E. A., \& Udende, B. M. (2017). Impact of IFRS adoption on accountability of Nigerian organisations. Journal of Economics and Finance, 8(1), 60-72.

[79] Nwoye, U. J., Chidoziem, A.M., Obiorah, J. \& Ekesiobi, C. (2017). Nigerian banks and global ranking: The IFRS compliance impact. The Nigerian Accountants, 50(2), 28-37.

[80] Adebisi, J, F., Otuagoma, F. O., \& Abah, A. O. (2017). Effect of international financial reporting standards disclosure compliance on the quality of financial reporting of deposit money banks in Nigeria. Nigerian Journal of Management Sciences, 6(1), 166-173.

[81] Eyenubo, S. A., Mohamed, M., \& Ali, M. (2017). An empirical analysis on the financial reporting quality of the quoted firms in Nigeria: Does audit committee size matter? International Journal of Academic Research in Business and Social Sciences, 7(9), 50-63.

[82] Kwaji, S. F., Ahmed, B. B., \&Ishaya, J. D. (2017). Impact of mandatory information disclosure on compliance with CAMA 2004. Saudi Journal of Business and Management Studies, 2(5B), 568-577.

[83] Onuorah, A. C., \& Imene, O. F. (2016). Corporate governance and financial reporting quality in selected Nigerian companies. International Journal of Management Science and Business Administration, 2(3), 7-16.

[84] Abata, M. A. (2015). Impact of IFRS on financial reporting practices in Nigeria (A case of KPMG). Global Journal of Contemporary Research in Accounting, Auditing and Business Ethics, 1(1), 263-281.

[85] Adetoso, J. A. (2014). Adoption and implementation of international financial reporting standards (IFRS) in Nigeria: Auditors perspectives. Journal of Emerging Trends in Economics and Management Sciences, 5(2), 108-112.

[86] Avgouleas, E. (2009). The global financial crisis and the disclosure paradigm in European financial regulation: The case for reform. European Company and Financial Law Review, 6(4), 440 475.

[87] Owolabi, S. O. (2018). Corporate governance and performance: A pathological exposition of Nigerian firms. Babcock University $21 \mathrm{st}$ Inaugural Lecture. Ilishan-Remo: Babcock University Press.

[88] Freeman, R. E. (2010). Strategic management: A stakeholder approach. Cambridge: Cambridge University Press. 
[89] Porter, M. E. \& Kramer, M. R. (2011). Creating shared value. Harvard Business Review, 89(1/2), 62-77.

[90] Bushman, R. M., Piotroski, J. D., \& Smith, A. J. (2004) What determines corporate transparency? Journal of Accounting Research, 42(2), 207-252.

[91] Tadesse, S. A. (2006). The economic value of regulated disclosure: Evidence from the banking sector. Journal of Accounting and Public Policy, 25(1), 32-70.

[92] Healy, P. M., \& Palepu, K. G. (2001). Information asymmetry, corporate disclosure, and the capital markets: A review of the empirical disclosure literature. Journal of Accounting and Economics, 31(1-3), 405-440.

[93] Yamene, T. (1973). Statistics: An introductory analysis. $3^{\text {rd }}$ Edition, Harper and Row, New York.

[94] Siyanbola, T. T., Enyi, E. P., Adegbie, F. F., \& Nwaobia, A. N. (2018) Mandatory disclosures and investment decisions in consumer goods sector of Nigerian economy. International Journal of Research \& Methodology in Social Science, 4(3), 49-67.

[95] World Bank (2004). Report on the Observance of Standards and Codes (ROSC) in Nigeria, Accounting and Auditing. Retrieved on
January
30 ,
2019

http://www.worldbank.org/ifa/rosc_aa_nga.pdf. 